Check for updates

Kent

Cite this as: BMJ 2021;374:n2162 http://dx.doi.org/10.1136/bmj.n2162 Published: 02 September 2021

\section{Covid-19: $80 \%$ of young adults in UK are likely to have antibodies, data suggest}

Jacqui Wise

Around eight in ten young adults in the UK are now likely to have SARS-CoV-2 antibodies either from past infection or because they have been vaccinated, the latest survey from the Office for National Statistics has shown. ${ }^{1}$

The fortnightly bulletin on antibody and vaccination levels in the UK community population includes data to 13 August on antibodies and to 8 August on vaccinations. The data are based on blood test results taken from a randomly selected subsample of people aged 16 and over.

In England $85.4 \%$ of $16-24$ year olds would test positive for antibodies, the survey suggests. The corresponding estimates are $85.6 \%$ for Scotland, $83.9 \%$ for Wales, and $80.4 \%$ for Northern Ireland.

Antibody levels in young people have increased rapidly in recent months, coinciding with the rollout of vaccines to younger age groups. In England the percentage of 16-24 year olds likely to have covid-19 antibodies had jumped from $52.9 \%$ in the week beginning 7 June to $85.4 \%$ by 13 August.

However, a proportion of this antibody protection has come from infection with SARS-CoV-2 rather than from vaccination, as in England only 58.1\% of 16-24 year olds have had any dose of a vaccine. The figure in Scotland is $54.6 \%$, Wales $52.6 \%$, and Northern Ireland $58.5 \%$.

\section{Older groups}

It takes two to three weeks after infection or vaccination for the body to make enough antibodies to fight the virus. An immune response does not rely on the presence of antibodies alone, as a person's $\mathrm{T}$ cell response will provide protection but not be detected by blood tests for antibodies.

Overall, over $90 \%$ of UK adults would have tested positive for antibodies against SARS-CoV-2. In England the figure is $94.1 \%$, in Wales $92 \%$, Scotland $93.6 \%$, and Northern Ireland $90.4 \%$.

The bulletin says that since the end of July 2021 antibody positivity has decreased in people aged 70 and over. But even in over 80s, 92\% would test positive for antibodies in England, 82\% in Wales, and $85 \%$ in Scotland. In Northern Ireland, where the data cannot be so finely grained because the sample size is smaller, the figure in over 70 is is $86 \%$. The NHS is planning a covid vaccine booster programme for older age groups and other vulnerable groups.

The Office for National Statistics commented, "In some regions and countries, we are starting to see a decline in the percentage of people testing positive for antibodies amongst the oldest age groups, although rates amongst these age groups remain high.

"Our analysis defines antibody positivity by a fixed amount of antibodies in the blood. Most older people who are vaccinated will retain higher antibody levels than prior to vaccination, but may have a lower number of antibodies in the blood at the time of testing."

1 Office for National Statistics. Coronavirus (covid-19) infection survey, antibody and vaccination data, UK: 1 September 2021. 1 Sep 2021.

https://www.ons.gov.uk/peoplepopulationandcommunity/healthandsocialcare/conditionsanddiseases/bulletins/coronaviruscovid19infectionsurveyantibodyandvaccinationdatafortheuk/1september2021

This article is made freely available for use in accordance with BMJ's website terms and conditions for the duration of the covid-19 pandemic or until otherwise determined by BMJ. You may use, download and print the article for any lawful, non-commercial purpose (including text and data mining) provided that all copyright notices and trade marks are retained. 